\title{
Synergistic Effect of PPFD and Mycorrhization for Efficient in vitro Propagation of Dendrobium chrysanthum Wall. ex Lindl.
}

\author{
Subarna Hajong ${ }^{1}$, Suman Kumaria ${ }^{2}$ and Pramod Tandon ${ }^{3}$ \\ ${ }^{1}$ ICAR-National Bureau of Plant Genetic Resources Regional Station Shillong, Umiam, \\ Meghalaya 793103, India \\ ${ }^{2}$ Plant Biotechnology Laboratory, Department of Botany, North-Eastern Hill University, \\ Shillong 793022, India \\ ${ }^{3}$ Biotech Park, Lucknow, Uttar Pradesh 226021, India \\ *Corresponding author
}

\section{A B S T R A C T}

\begin{tabular}{|c|}
\hline Keywords \\
\hline $\begin{array}{l}\text { Dendrobium } \\
\text { chrysanthum, Ex } \\
\text { vitro, In vitro } \\
\text { Mycorrhization, } \\
\text { PPFD }\end{array}$ \\
\hline Article Info \\
\hline $\begin{array}{l}\text { Accepted: } \\
12 \text { September } 2019 \\
\text { Available Online: } \\
10 \text { October } 2019\end{array}$ \\
\hline
\end{tabular}

\section{Introduction}

Orchids of the family Orchidaceae are one of the largest angiosperm families of the plant kingdom. Over the past 40 years orchids have been subjected to high commercial demand for their beautiful and vivid colored flowers, delicate scents and medicinal properties. However, increased biotic influences e.g., deforestation, socio-economic development and excessive exploitation for commercial purposes have led to a considerable depletion 
of orchids in nature. Due to tremendous pressure on orchids in nature, the entire family "Orchidaceae" is listed in the Appendices of the Convention on International Trade in Endangered Species of Wild Fauna and Flora (CITES) for conservation. Many programs have been initiated for the conservation of orchids. In vitro culture via micropropagation is an important technique for ex situ conservation and management of plant genetic resources. Large quantities of uniform, highvalue plants can be produced through micropropagation. However, conventional micropropagation is carried out under abnormal growth conditions such as high relative humidity, constant temperature, low photosynthetic photon flux density (PPFD), large diurnal fluctuation in $\mathrm{CO}_{2}$ concentration, etc. (Debergh et al.,1992; Cui et al., 2000). As a result, structural and functional abnormalities have been observed in micropropagated plants which make these plants susceptible to photoinhibition upon transfer to ex vitro environment (Capellades et al., 1990; Zimmerman et al., 1991). It is generally accepted that poor photosynthetic behavior is one of the most important abnormalities hindering ex vitro acclimatization of micropropagated plants. Abnormalities induced in vitro could be "corrected" by adjusting different environmental parameters in vitro (Debergh, 1991). Earlier studies have also shown that photosynthetic efficiency could be improved by raising PPFD during acclimatization (Amancio et al., 1999).

The survival percentage and growth of micropropagated plants could also be improved by treatment with mycorrhizal fungi during acclimatization. Mycorrhizal association increased the resistance of plants to environmental stresses by stimulating growth regulators, increasing photosynthesis, and improving regulation of osmotic adjustment (Rabie and Almadani, 2005). The photosynthetic system is also known to be protected by associated mycorrhiza from overreduction and photoinhibition. Contrary to mycorrhizal inoculation during acclimatization, induction of mycorrhizal association in plantlets under in vitro conditions provide an interesting model system to examine the hypothesis that colonization of roots in vitro would provide a certain degree of stress tolerance during acclimatization ex vitro. Studies on the physiology and behavior of these plants in controlled environments are also possible. In vitro systems have been extensively used as tools to discover and elucidate the nature of chemical dialogue between roots and fungi prior to and during the process of mycorrhization (Martin et al., 2001; Pierleoni et al., 2001).

Mycorrhizal association prior to transplantation has been suggested to be a better strategy for plants against the biotic and abiotic stresses that occur in greenhouses or in the field (Vestberg et al., 2004). Furthermore, by introducing mycorrhizal fungi at an early stage, it would be possible to reduce the use of fertilizer and pesticides and allow the plants to grow in a more sustainable way (Cordier et al., 2000).

The aim of the present study was to develop an effective protocol for maximum growth and survival of orchids by integrating optimal PPFD and mycorrhization in vitro.

Dendrobium chrysanthum (Fig. 1), being a medicinally important and endangered orchid of North-east India, has been selected as a model plant for the present study. The objectives of the investigation were designed to study the effect of optimal PPFD and mycorrhization (i) on the growth of $D$. chrysanthum plants in vitro, and (ii) establishment vis-a-vis growth of micropropagated plants post-transplantation. 


\section{Materials and Methods}

\section{Establishment of mycorrhizal association in vitro at different PPFDs}

For mycorrhizal association in vitro, the procedures described by Hajong et al., (2012, 2013) were followed. Plantlets measuring around $1-1.5 \mathrm{~cm}$ obtained from in vitro nodal explants of $D$. chrysanthum were used for the experiment. About $20 \mathrm{~mL}$ of oat meal agar medium (OMA-NC, modified from Rasmussen et al., 1990) was poured into the Erlenmeyer flasks (Table 1). Five plantlets per flask were inoculated in the medium at uniform distances from each other in a circle. Simultaneously, blocks $\left(1 \times 1 \mathrm{~mm}^{2}\right)$ of the fungal isolate 4634 [isolated from Ipomoea batatas and obtained from Institute of Microbial Technology (IMTECH), Chandigarh, India] were inoculated in the centre of the circle. The flasks without fungal inoculum were maintained as controls or nonmycorrhizal plantlets. A light gradient was established by placing the flasks at different PPFD (20, 40, 60 and $80 \mu$ moles $\mathrm{m}^{-2} \mathrm{~s}^{-1}$ ) supplied by cool white fluorescent lamps in BOD incubators. PPFD was measured (on top of the culture flasks) with a Lux meter (Lutron LX-101) and the value obtained was converted

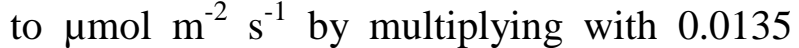
(conversion factor for cool white fluorescent lamps, Thimijan and Heins, 1982). The temperature of the BOD incubator was maintained at $25 \pm 2{ }^{\circ} \mathrm{C}$, photoperiod at $12 \mathrm{~h}$ and relative humidity at $70-80 \%$.

\section{Assessment of root colonization}

Root colonization percentage was calculated from plants cultured at different light treatments. For assessment of root colonization, the slide method proposed by Giovannetti and Mosse (1998) was followed. A total of 30 root-segments $(0.5 \mathrm{~cm}$ long), from each treatment, were selected at random from the stained samples and mounted on microscopic slide in groups of 10 . Presence of infection was recorded in each of the 10 pieces, and percentage infection was calculated as:

$\%$ root colonization $=$ (number of root segments colonized $\div$ total number of root segments observed) $\mathrm{X} 100$

\section{Growth and total chlorophyll content of plantlets under in vitro conditions}

The growth parameters namely, shoot length, number of leaves, leaf area, number of roots, root length, fresh weight (FW), dry weight (DW) and total chlorophyll content of $D$. chrysanthum grown at different PPFDs were measured after 30, 60 and $90 \mathrm{~d}$ of treatment. Additionally, stomata number and size were also observed after $90 \mathrm{~d}$. To determine DW, plantlets were dried at $120^{\circ} \mathrm{C}$ for $20 \mathrm{~min}$ in a Sartorius moisture balance (MA-35) and their DW measured. Leaf area was measured with the help of a Leaf area meter (Systronics Leaf Area Meter 211).

Stomata number and size were determined by light microscope and Scanning Electron Microscope (SEM) observations of the lower epidermis of fully developed leaves. For SEM observation, segments of the fully developed leaves were cut into $3 \times 3 \mathrm{~mm}^{2}$ pieces and fixed in $3 \%$ glutaraldehyde for $2 \mathrm{~h}$ at $4{ }^{\circ} \mathrm{C}$. These leaf segments were washed twice in 0.1 $\mathrm{M}$ sodium cacodylate buffer at $4{ }^{\circ} \mathrm{C}$ for $15 \mathrm{~min}$ each. Dehydration was carried out with different grades of acetone (30-100\%). The segments were immersed in tetramethylsilane for 5-10 min. The process was repeated and then mounted on brass stubs and gold coated. Finally, the segments were observed under SEM.

For estimation of chlorophyll content, fresh leaf tissue $(0.1 \mathrm{~g})$ was crushed in $1 \mathrm{~mL}$ of pure 
acetone (100\%), centrifuged at 5,000g for 10 $\min \quad$ at $4 \quad{ }^{\circ} \mathrm{C}$ and quantified spectrophotometrically. Chlorophyll ' $a$ ' was determined at wavelength $661.6 \mathrm{~nm}$ and Chlorophyll 'b' at $644.8 \mathrm{~nm}$ (Lichtenthaler, 1987).

Survival, growth and total chlorophyll content of hardened mycorrhizal and nonmycorrhizal plantlets

Mycorrhizal and non-mycorrhizal plantlets of D. chrysanthum cultured in vitro at different PPFD for $90 \mathrm{~d}$ were taken for hardening.

Plantlets were taken out from the culture flasks by means of forceps and gently washed with sterile distilled water, then transferred to clean thermocol pots containing compost mix of approximately $1-1.5 \mathrm{~cm}^{3}$ of brick pieces and charcoal chunks, chopped decaying litter and moss in a ratio of 1:1:1:1(Hajong et al., 2013).

Prior to putting in the thermocol pots the compost mix was washed thoroughly with tap water, rinsed twice with sterile distilled water, air dried and autoclaved for $60 \mathrm{~min}$ at $121^{\circ} \mathrm{C}$.

A single plantlet was transferred to each thermocol pot. Survival percentage and plant growth parameters viz., number of shoots, shoot length, number of leaves, leaf area, number of roots, root length, FW, DW and total chlorophyll content were measured after $120 \mathrm{~d}$ of transfer to the green house.

\section{Statistical analysis}

Twenty replicates were maintained for every treatment with each Erlenmeyer flask being one replication and the experiment was repeated thrice. Data was subjected to oneway analysis of variance (ANOVA) using Origin (ver. 8.0), and means were compared using least significant difference (LSD) at $\mathrm{p}<0.05$ significance level.

\section{Results and Discussion}

\section{Root colonization}

The results obtained from the studies on percentage of root colonization at different PPFD treatments in vitro indicated that percentage of root colonization is related to PPFD. The highest percentage of root colonization (73\%) by fungal isolate 4634 was recorded at $60 \mu \mathrm{mol} \mathrm{m} \mathrm{s}^{-2} \mathrm{~s}^{-1}$ and the lowest percentage of root colonization was observed at $80 \mu \mathrm{mol} \mathrm{m} \mathrm{s}^{-1}$ (Fig. 2). At $40 \mu \mathrm{mol} \mathrm{m} \mathrm{m}^{-1} \mathrm{~s}^{-1}$ PPFD percentage of root colonization (44\%) was lower than the percentage recorded at 60 $\mu \mathrm{mol} \mathrm{m} \mathrm{s}^{-1} \mathrm{~s}^{-1}$ while at $20 \mu \mathrm{mol} \mathrm{m} \mathrm{s}^{-2} \mathrm{PPFD}$, percentage of root colonization (35.3\%) was less than the percentage observed at $40 \mu \mathrm{mol}$ $\mathrm{m}^{-2} \mathrm{~s}^{-1}$. However, the lowest percentage of root colonization was observed at $80 \mu \mathrm{mol} \mathrm{m} \mathrm{s}^{-2}$.

Growth and total chlorophyll content of mycorrhizal and non-mycorrhizal plantlets under in vitro conditions

The morphological features of mycorrhizal and non-mycorrhizal $D$. chrysanthum plantlets growing at different in vitro PPFD treatments were recorded. The mycorrhizal plantlets showed relatively better growth (with the exception of number of roots and root length) than non-mycorrhizal plantlets under all PPFD treatments. After $30 \mathrm{~d}$, the shoot length (1.64 $\mathrm{cm})$ attained by mycorrhizal plantlets cultured under $60 \mu \mathrm{mol} \mathrm{m} \mathrm{s}^{-2} \mathrm{~s}^{-1}$ PPFD was significantly higher than the other treatments (Table 2). Number of leaves (5.20) of mycorrhizal plantlets was significantly higher than the nonmycorrhizal plantlets at the same PPFD, but was comparable to number of leaves (5.03) of mycorrhizal plantlets at $40 \mu \mathrm{mol} \mathrm{m} \mathrm{m}^{-2} \mathrm{~s}^{-1}$ PPFD (Table 2). Leaf area $\left(0.77 \mathrm{~cm}^{2}\right.$ leaf $\left.^{-1}\right), \mathrm{FW}$ $(0.079 \mathrm{~g})$ and DW $(0.0068 \mathrm{~g})$ were observed to be highest in mycorrhizal plantlets at $60 \mu \mathrm{mol}$ $\mathrm{m}^{-2} \mathrm{~s}^{-1}$ PPFD (Table 2). No significant difference was recorded in number of roots 
and root length of plantlets at the different PPFDs (Table 2). Besides affecting the growth and morphological characteristics of plantlets, PPFD levels also influenced total chlorophyll content. Highest concentration of chlorophyll content was observed in mycorrhizal plantlets at $60 \mu \mathrm{mol} \mathrm{m} \mathrm{m}^{-2} \mathrm{~s}^{-1}$ PPFD (Table 2). After $60 \mathrm{~d}$ of culture, significant increases in shoot length $(1.71 \mathrm{~cm})$, leaf area $\left(0.90 \mathrm{~cm}^{2}\right.$ leaf $\left.^{-1}\right)$, FW $(0.084 \mathrm{~g})$, DW $(0.0072 \mathrm{~g})$ and total chlorophyll content $(0.56 \mathrm{mg} / \mathrm{g} \quad \mathrm{FW})$ in mycorrhizal plantlets at $60 \mu \mathrm{mol} \mathrm{m} \mathrm{m}^{-2} \mathrm{~s}^{-1}$ PPFD were recorded (Table 3). A significant difference in the number of leaves was observed in mycorrhizal and non-mycorrhizal plantlets at $60 \mu \mathrm{mol} \mathrm{m} \mathrm{m}^{-2} \mathrm{~s}^{-1}$ PPFD. However, the number of leaves of mycorrhizal plantlets at $60 \mu \mathrm{mol} \mathrm{m} \mathrm{m}^{-2} \mathrm{~s}^{-1}$ PPFD did not increase significantly but was slightly higher than mycorrhizal plantlets at $40 \mu \mathrm{mol} \mathrm{m} \mathrm{m}^{-2}$ PPFD (Table 3). No significant difference was recorded in number of roots and root length of plantlets at the different PPFD treatments (Table 3). Similar pattern of growth response was also observed after $90 \mathrm{~d}$ of culture. Shoot length $(1.75 \mathrm{~cm})$, leaf area $\left(1.13 \mathrm{~cm}^{2}\right.$ leaf $\left.{ }^{-1}\right)$, FW $(0.090 \mathrm{~g})$ and total chlorophyll content $(0.59 \mathrm{mg} / \mathrm{g} \mathrm{FW})$ of mycorrhizal plantlets increased significantly at $60 \mu \mathrm{mol} \mathrm{m} \mathrm{m}^{-2} \mathrm{~s}^{-1}$ PPFD (Table 4, Fig. 3). Number of leaves (6.33) and DW (0.0078 g) in mycorrhizal plantlets at $60 \mu \mathrm{mol} \mathrm{m} \mathrm{m}^{-2} \mathrm{~s}^{-1}$ PPFD were significantly higher than the non-mycorrhizal plantlets at the same PPFD (Table 4). Number of leaves and DW in mycorrhizal plantlets at 40 and $60 \mu \mathrm{mol} \mathrm{m} \mathrm{m}^{-2}$ PPFD were, however, not significantly different (Table 4). Number of roots and root length did not undergo any significant change at the different PPFDs at 90 $\mathrm{d}$ of treatment (Table 4). Light intensity also appeared to affect development of stomata. An increase in number of stomata per unit area of leaf at $90 \mathrm{~d}$ of treatment was recorded with increasing light intensity (Table 4, Fig. 4). SEM examinations revealed that length of stomata was found to be maximum in mycorrhizal plantlets at $60 \mu \mathrm{mol} \mathrm{m} \mathrm{m}^{-2} \mathrm{~s}^{-1}$ PPFD but light intensity did not cause any substantial effect on width of stomata (Table 4, Fig. 4).

Effect of in vitro PPFD treatment on the survival, growth and total chlorophyll content of hardened mycorrhizal and nonmycorrhizal plantlets

Mycorrhizal as well as non-mycorrhizal plantlets of $D$. chrysanthum cultured in vitro at different PPFD treatments were taken for hardening. Observations on survival percentage; growth parameters and total chlorophyll content were made after $120 \mathrm{~d}$ of transfer to the greenhouse. Highest percentage of survival $(97.33 \%)$ was obtained with mycorrhizal plantlets transferred from 60 $\mu \mathrm{mol} \mathrm{m} \mathrm{m}^{-2}$ PPFD (Fig. 5). The growth characteristics viz., number of shoots (1.33), shoot length $(3.72 \mathrm{~cm})$, number of leaves (6.20), leaf area $\left(3.52 \mathrm{~cm}^{2}\right.$ leaf $\left.{ }^{-1}\right)$, number of roots $(7)$, root length $(5.30 \mathrm{~cm}), \mathrm{FW}(0.369 \mathrm{~g})$, DW (0.0371 g) and total chlorophyll content $(0.55 \mathrm{mg} / \mathrm{g} \mathrm{FW})$ of mycorrhizal plantlets transferred from $60 \mu \mathrm{mol} \mathrm{m} \mathrm{m}^{-2} \mathrm{~s}^{-1}$ PPFD were recorded to be highest as compared to the others (Table 5, Fig. 6).

The interactions between efficiency of mycorrhiza and light are complex as light not only influences the plant growth through photosynthesis, but also through its effects on other factors (Fitter and Garbaye, 1994). Associated mycorrhizal fungi enhance the ability of plants to overcome low availability of nutrient resources by improving the uptake of low-mobility nutrients. The fungi in return receive an estimated $4-20 \%$ of the net photosynthates for its growth and maintenance (Fitter, 1991; Smith and Read, 1997). In the present study, PPFD treatment of $60 \mu \mathrm{mol} \mathrm{m}$ ${ }^{2} \mathrm{~s}^{-1}$ was found to be optimum for root colonization (73\%) by the fungal isolate 4634 . The amount of light received by the host plant 
is believed to directly influence the development of mycorrhiza. Concentration of root exudates and soluble carbohydrates in the roots are considered to be important for the establishment of mycorrhizal infection both of which are known to decrease at low irradiance (Ferguson and Menge, 1982; Johnson et al., 1982). The reduced mycorrhizal colonization under low irradiance has also been hypothesized to be due to competition between the host plant and fungus for carbon (Tester et al., 1985).

Higher irradiance on the other hand, has been reported to stimulate mycorrhizal infections in plants (Peyronel, 1940; Daft and El-Giahmi, 1978). The low percentage of fungal root colonization observed at $80 \mu \mathrm{mol} \mathrm{m} \mathrm{s}^{-2} \mathrm{~s}^{-1}$ in the study could be due to competition for limited resources between the fungi and the plant as high light irradiance is known to cause photoinhibition which impairs the photosynthetic ability of the plant (Powles 1984).

The growth of mycorrhizal plantlets was observed to be better at $60 \mu \mathrm{mol} \mathrm{m} \mathrm{s}^{-2}$ PPFD as compared to plantlets subjected to either lower or higher PPFD. Earlier, reports indicated that highest level of mycorrhizal colonization and hence greater photosynthesis and better growth of mycorrhizal plants occurred under the light conditions that were most favorable for photosynthesis and growth of the host plants (Prajadinata and Santoso, 1993; Bereau et al., 2000). Under in vitro conditions, the growth responses in terms of shoot length, leaf area, FW and DW of mycorrhizal plantlets were consistently and significantly higher at $60 \mu \mathrm{mol} \mathrm{m} \mathrm{s}^{-2} \mathrm{~s}^{-1}$ PPFD. Johnson et al., (1982) observed greater growth, photosynthesis and stomatal conductance of mycorrhizal plants of sweet orange at higher light intensity. Increased plant growth under favorable light and temperature had also been reported as a result of mycorrhizal association in onions (Hayman, 1974). In the present study, number of roots and root length did not undergo any significant change at the different PPFD treatments, however, it was observed that at lower PPFD, the number and length of roots were slightly reduced.

Lower PPFD reduced the growth rate of root length probably by reducing the rate of initiation of lateral roots, and to a smaller extent by reducing the average rate of root tip extension. In this study, though, direct photosynthesis and stomatal conductance were not measured but significant increase in total chlorophyll content and number of stomata in mycorrhizal plantlets was observed at $60 \mu \mathrm{mol}$ $\mathrm{m}^{-2} \mathrm{~s}^{-1}$. Chlorophyll content has been suggested to be a good indicator of the photosynthetic apparatus status (Alvarez et al., 2012). Jo et al., (2008) observed that PPFD level of 30 $\mu \mathrm{mol} \mathrm{m} \mathrm{m}^{-2} \mathrm{~s}^{-1}$ was found to support maximum concentrations of chlorophyll "a", chlorophyll "b" and carotenoids in Alocasia amzonica.

Earlier, Jeon et al., (2005) also reported similar increase in a CAM orchid, Doritaenopsis which had highest concentration of total chlorophyll at low and intermediate PPFD level compared to those grown at high PPFD levels. According to Demmig-Adams and Adams III (1992), at high PPFD of $90 \mu \mathrm{mol} \mathrm{m} \mathrm{m}^{-2} \mathrm{~s}^{-1}$, decrease in chlorophyll and carotenoid contents could be correlated to accelerated degeneration of these pigments.

Additionally, in this study, the development of mycorrhizal association might have led to increased growth, photosynthetic pigments and photosynthesis of host plants by enhancing the availability of mineral nutrition. Mycorrhizal association was observed to enhance chlorophyll content in Malus pruniolia (Guan, 2007). 
Table.1 Composition of oat meal agar medium (OMA-NC, modified from [15]) used for mycorrhizal association experiment

\begin{tabular}{|c|c|}
\hline Constituents & $\mathbf{m M}$ \\
\hline $\mathbf{N H}_{4} \mathbf{N O}_{3}$ & 1.0 \\
\hline $\mathrm{KH}_{\mathbf{2}} \mathbf{P O}_{\mathbf{4}}$ & 1.5 \\
\hline $\mathbf{M g S O}_{\mathbf{4} .7 \mathbf{H}_{2}} \mathbf{O}$ & 0.4 \\
\hline KCl & 0.9 \\
\hline Cellulose & $2.0 \mathrm{~g}$ \\
\hline Yeast Extract & $0.1 \mathrm{~g}$ \\
\hline Oat Meal Powder & $3.0 \mathrm{~g}$ \\
\hline Agar & $6.0 \mathrm{~g}$ \\
\hline pH & 5.8 \\
\hline
\end{tabular}

Table.2 Effect of PPFD on growth and total chlorophyll content in non-mycorrhizal and mycorrhizal plantlets of Dendrobium chrysanthum after 30 days of culture

\begin{tabular}{|c|c|c|c|c|c|c|c|c|}
\hline \multirow[t]{3}{*}{ Parameters } & \multicolumn{8}{|c|}{ PPFD $\left(\mu \mathrm{mol} \mathrm{m} \mathrm{m}^{-2}\right)$} \\
\hline & \multicolumn{2}{|c|}{20} & \multicolumn{2}{|c|}{40} & \multicolumn{2}{|c|}{60} & \multicolumn{2}{|c|}{80} \\
\hline & NM & M & NM & M & NM & M & NM & M \\
\hline Shoot Length (cm) & $1.35 \pm 0.03^{\mathrm{cd}}$ & $1.42 \pm 0.03^{\mathrm{bcd}}$ & $1.42 \pm 0.03^{\mathrm{bcd}}$ & $1.49 \pm 0.02^{b}$ & $1.44 \pm 0.03^{\mathrm{bc}}$ & $1.64 \pm 0.02^{\mathrm{a}}$ & $1.24 \pm 0.04^{\mathrm{e}}$ & $1.33 \pm 0.03^{\mathrm{de}}$ \\
\hline No. of Leaves & $3.75 \pm 0.13^{b}$ & $3.93 \pm 0.15^{\mathrm{b}}$ & $4.00 \pm 0.14^{b}$ & $5.03 \pm 0.12^{\mathrm{a}}$ & $4.06 \pm 0.14^{b}$ & $5.20 \pm 0.17^{\mathrm{a}}$ & $3.63 \pm 0.12^{b}$ & $3.73 \pm 0.12^{b}$ \\
\hline $\begin{array}{c}\text { Leaf Area } \mathrm{cm}^{2} \\
\text { leaf }^{-1}\end{array}$ & $0.47 \pm 0.02^{\mathrm{cd}}$ & $0.48 \pm 0.02^{\mathrm{cd}}$ & $0.48 \pm 0.01^{\mathrm{cd}}$ & $0.50 \pm 0.02^{b c}$ & $0.55 \pm 0.02^{b}$ & $0.77 \pm 0.03^{\mathrm{a}}$ & $0.41 \pm 0.01^{\mathrm{e}}$ & $0.44 \pm 0.01^{\mathrm{de}}$ \\
\hline No. of Roots & $2.23 \pm 0.09^{b}$ & $2.43 \pm 0.09^{\mathrm{ab}}$ & $2.33 \pm 0.09^{\mathrm{ab}}$ & $2.43 \pm 0.03^{\mathrm{ab}}$ & $2.36 \pm 0.09^{\mathrm{ab}}$ & $2.53 \pm 0.09^{a}$ & $2.33 \pm 0.12^{\mathrm{ab}}$ & $2.36 \pm 0.11^{\mathrm{ab}}$ \\
\hline Root Length (cm) & $0.55 \pm 0.01^{b}$ & $0.56 \pm 0.01^{b}$ & $0.73 \pm 0.03^{\mathrm{a}}$ & $0.76 \pm 0.03^{\mathrm{a}}$ & $0.72 \pm 0.03^{\mathrm{a}}$ & $0.79 \pm 0.04^{\mathrm{a}}$ & $0.55 \pm 0.01^{\mathrm{a}}$ & $0.56 \pm 0.01^{\mathrm{a}}$ \\
\hline Fresh Weight (g) & $0.057 \pm 0^{\mathrm{de}}$ & $0.065 \pm 0^{c}$ & $0.061 \pm 0^{\text {cd }}$ & $0.071 \pm 0^{\mathrm{b}}$ & $0.065 \pm 0^{\mathrm{c}}$ & $0.079 \pm 0^{\mathrm{a}}$ & $0.054 \pm 0^{\mathrm{e}}$ & $0.058 \pm 0^{\mathrm{de}}$ \\
\hline Dry weight (g) & $0.0042 \pm 0^{\mathrm{d}}$ & $0.005 \pm 0^{c}$ & $0.005 \pm 0^{\mathrm{d}}$ & $0.0064 \pm 0^{\mathrm{ab}}$ & $0.0062 \pm 0^{b c}$ & $0.0068 \pm 0^{\mathrm{a}}$ & $0.005 \pm 0^{d}$ & $0.006 \pm 0^{b c}$ \\
\hline $\begin{array}{l}\text { Total Chlorophyll } \\
\text { (mg/g fr. wt.) }\end{array}$ & $0.37 \pm 0^{\mathrm{e}}$ & $0.41 \pm 0.01^{d}$ & $0.41 \pm 0.3^{\mathrm{d}}$ & $0.45 \pm 0^{\mathrm{c}}$ & $0.47 \pm 0^{\mathrm{b}}$ & $0.49 \pm 0^{\mathrm{a}}$ & $0.26 \pm 0^{\mathrm{g}}$ & $0.31 \pm 0.01^{f}$ \\
\hline
\end{tabular}

NM-non-mycorrhizal; M-mycorrhizal; values are mean \pm SE; means followed by different letters in the same row are significantly different at $\mathrm{p}<0.05$ 
Table.3 Effect of PPFD on growth and total chlorophyll content in non-mycorrhizal and mycorrhizal plantlets of Dendrobium chrysanthum after 60 days of culture

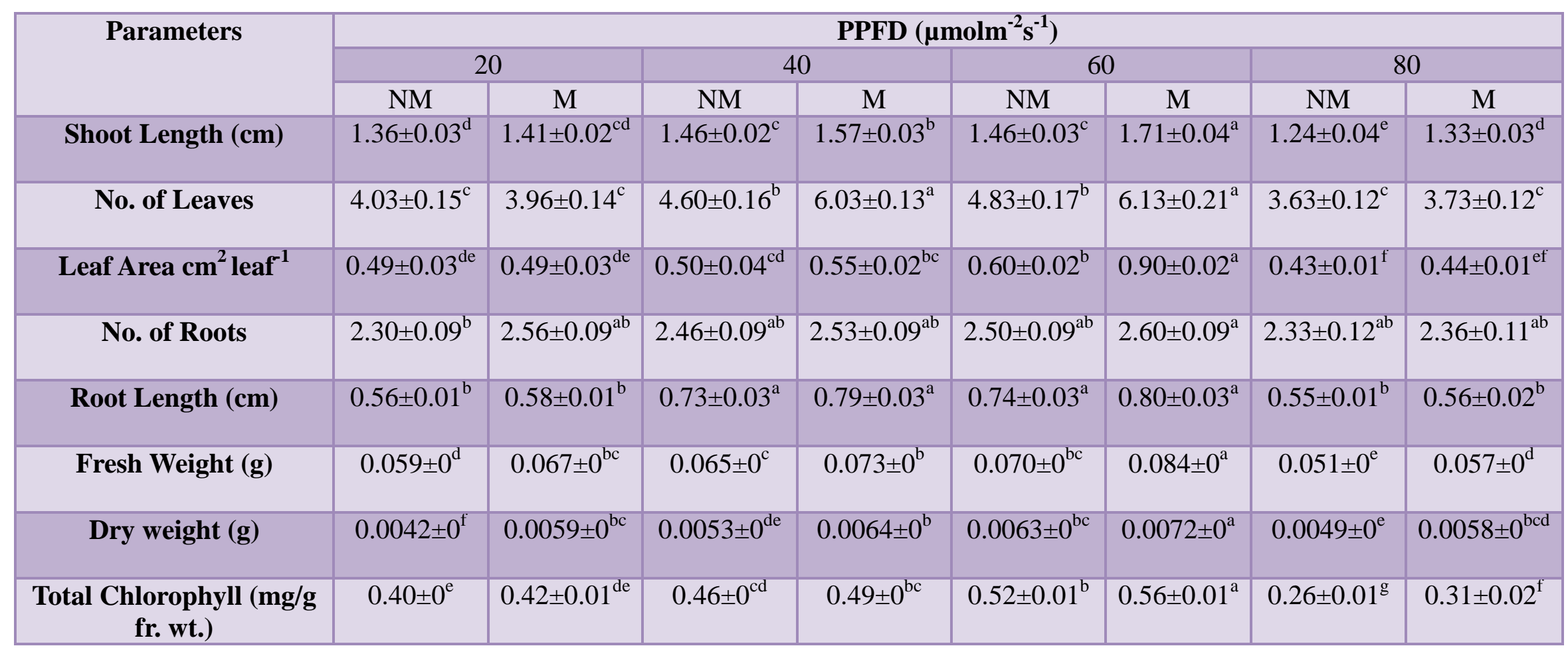

NM-non-mycorrhizal; M-mycorrhizal; values are mean \pm SE; means followed by different letters in the same row are significantly different at $\mathrm{p}<0.05$ 
Table.4 Effect of PPFD on growth, total chlorophyll content and stomatal attributes in non-mycorrhizal and mycorrhizal plantlets of Dendrobium chrysanthum after 90 days of culture

\begin{tabular}{|c|c|c|c|c|c|c|c|c|}
\hline \multirow[t]{3}{*}{ Parameters } & \multicolumn{8}{|c|}{ PPFD $\left(\mu \mathrm{molm}^{-2} \mathrm{~s}^{-1}\right)$} \\
\hline & \multicolumn{2}{|c|}{20} & \multicolumn{2}{|c|}{40} & \multicolumn{2}{|c|}{60} & \multicolumn{2}{|c|}{80} \\
\hline & NM & $\mathrm{M}$ & NM & M & NM & M & $\mathrm{NM}$ & $\mathrm{M}$ \\
\hline Shoot Length $(\mathrm{cm})$ & $1.39 \pm 0.03^{\mathrm{de}}$ & $1.45 \pm 0.01^{\mathrm{cd}}$ & $1.50 \pm 0.02^{c}$ & $1.62 \pm 0.03^{b}$ & $1.50 \pm 0.02^{c}$ & $1.75 \pm 0.04^{\mathrm{a}}$ & $1.24 \pm 0.04^{\mathrm{f}}$ & $1.33 \pm 0.03^{\mathrm{e}}$ \\
\hline No. of Leaves & $4.23 \pm 0.16^{\mathrm{c}}$ & $4.50 \pm 0.13^{b c}$ & $4.73 \pm 0.14^{b}$ & $6.26 \pm 0.14^{\mathrm{a}}$ & $4.96 \pm 0.21^{b}$ & $6.33 \pm 0.22^{\mathrm{a}}$ & $3.63 \pm 0.12^{d}$ & $3.73 \pm 0.12^{d}$ \\
\hline Leaf Area $\mathrm{cm}^{2}$ leaf $^{-1}$ & $0.61 \pm 0.03^{c}$ & $0.62 \pm 0.03^{b c}$ & $0.62 \pm 0.03^{b c}$ & $0.65 \pm 0.02^{\mathrm{bc}}$ & $0.71 \pm 0.03^{b}$ & $1.13 \pm 0.06^{\mathrm{a}}$ & $0.43 \pm 0.01^{d}$ & $0.44 \pm 0.01^{d}$ \\
\hline No. of Roots & $2.40 \pm 0.09^{\mathrm{cd}}$ & $2.73 \pm 0.08^{\mathrm{ab}}$ & $2.56 \pm 0.09^{\mathrm{bcd}}$ & $2.63 \pm 0.09^{a b c}$ & $2.66 \pm 0.09^{\mathrm{ab}}$ & $2.83 \pm 0.07^{\mathrm{a}}$ & $2.33 \pm 0.12^{d}$ & $2.36 \pm 0.11^{d}$ \\
\hline Root Length (cm) & $0.57 \pm 0.01^{b}$ & $0.59 \pm 0.01^{b}$ & $0.75 \pm 0.02^{\mathrm{a}}$ & $0.80 \pm 0.03^{\mathrm{a}}$ & $0.75 \pm 0.03^{\mathrm{a}}$ & $0.83 \pm 0.03^{\mathrm{a}}$ & $0.55 \pm 0.01^{b}$ & $0.56 \pm 0.01^{b}$ \\
\hline Fresh Weight (g) & $0.062 \pm 0^{\mathrm{de}}$ & $0.068 \pm 0^{\mathrm{cd}}$ & $0.066 \pm 0^{d}$ & $0.076 \pm 0^{b}$ & $0.075 \pm 0^{b c}$ & $0.090 \pm 0^{\mathrm{a}}$ & $0.049 \pm 0^{f}$ & $0.056 \pm 0^{\text {ef }}$ \\
\hline Dry Weight (g) & $0.0054 \pm 0^{\mathrm{cd}}$ & $0.006 \pm 0^{c}$ & $0.0062 \pm 0^{\mathrm{bc}}$ & $0.0071 \pm 0^{\mathrm{ab}}$ & $0.0064 \pm 0^{b c}$ & $0.0078 \pm 0^{\mathrm{a}}$ & $0.0046 \pm 0^{d}$ & $0.0054 \pm 0^{\mathrm{cd}}$ \\
\hline Total Chlorophyll (mg/g fr. wt.) & $0.42 \pm 0^{\mathrm{e}}$ & $0.44 \pm 0^{\mathrm{d}}$ & $0.48 \pm 0.01^{\mathrm{c}}$ & $0.53 \pm 0.01^{b}$ & $0.54 \pm 0.01^{b}$ & $0.59 \pm 0^{\mathrm{a}}$ & $0.13 \pm 0.01^{\mathrm{g}}$ & $0.21 \pm 0.01^{\mathrm{f}}$ \\
\hline No. of Stomata $\left(\mathrm{mm}^{-2}\right)$ & $48.87 \pm 0.62^{\mathrm{g}}$ & $67.60 \pm 0.61^{f}$ & $71.00 \pm 0.58^{\mathrm{e}}$ & $93.30 \pm 0.95^{\mathrm{d}}$ & $97.17 \pm 0.54^{c}$ & $108.30 \pm 0.54^{b}$ & $123.73 \pm 0.53^{\mathrm{a}}$ & $125.67 \pm 0.15^{\circ}$ \\
\hline Length of Stomata $(\boldsymbol{\mu m})$ & $3.15 \pm 0.05^{\mathrm{c}}$ & $3.23 \pm 0.06^{\mathrm{bc}}$ & $3.20 \pm 0.05^{\mathrm{bc}}$ & $2.95 \pm 0.06^{\mathrm{d}}$ & $3.31 \pm 0.05^{b}$ & $3.46 \pm 0.05^{\mathrm{a}}$ & $2.78 \pm 0.05^{\mathrm{e}}$ & $2.80 \pm 0.05^{\mathrm{de}}$ \\
\hline Width of Stomata ( $\mu \mathrm{m})$ & $2.28 \pm 0.06^{\mathrm{cd}}$ & $2.26 \pm 0.05^{\mathrm{d}}$ & $2.44 \pm 0.07^{\mathrm{bc}}$ & $2.51 \pm 0.08^{b}$ & $2.57 \pm 0.07^{\mathrm{ab}}$ & $2.71 \pm 0.06^{\mathrm{a}}$ & $2.10 \pm 0.04^{\mathrm{e}}$ & $2.20 \pm 0.05^{\mathrm{de}}$ \\
\hline
\end{tabular}

NM-non-mycorrhizal; M-mycorrhizal; values are mean \pm SE; means followed by different letters in the same row are significantly different at $p<0.05$ 
Table.5 Effect of in vitro PPFD on growth and total chlorophyll content in non-mycorrhizal and mycorrhizal plantlets of Dendrobiumchrysanthum after $120 \mathrm{~d}$ of hardening

\begin{tabular}{|c|c|c|c|c|c|c|}
\hline \multirow[t]{3}{*}{ Parameters } & \multicolumn{6}{|c|}{ PPFD $\left(\mu \mathrm{molm}^{-2} \mathrm{~s}^{-1}\right)$} \\
\hline & \multicolumn{2}{|c|}{20} & \multicolumn{2}{|c|}{40} & \multicolumn{2}{|c|}{60} \\
\hline & NM & M & NM & M & NM & M \\
\hline No. of shoots & $1.00 \pm 0^{b}$ & $1.00 \pm 0^{b}$ & $1.00 \pm 0^{b}$ & $1.00 \pm 0^{b}$ & $1.00 \pm 0^{b}$ & $1.33 \pm 0.09^{\mathrm{a}}$ \\
\hline Shoot Length (cm) & $1.46 \pm 0.02^{\mathrm{d}}$ & $1.73 \pm 0.03^{\mathrm{c}}$ & $1.59 \pm 0.01^{d}$ & $1.84 \pm 0.06^{\mathrm{c}}$ & $2.11 \pm 0.04^{b}$ & $3.72 \pm 0.07^{\mathrm{a}}$ \\
\hline No. of Leaves & $2.33 \pm 0.09^{d}$ & $2.50 \pm 0.09^{d}$ & $3.47 \pm 0.1^{\mathrm{c}}$ & $3.77 \pm 0.13^{c}$ & $4.20 \pm 0.14^{b}$ & $6.20 \pm 0.11^{\mathrm{a}}$ \\
\hline Leaf Area $\mathrm{cm}^{2}$ leaf $^{-1}$ & $0.76 \pm 0.01^{\mathrm{c}}$ & $0.82 \pm 0.02^{c}$ & $0.82 \pm 0.02^{c}$ & $0.91 \pm 0.02^{c}$ & $1.20 \pm 0.06^{b}$ & $3.52 \pm 0.12^{a}$ \\
\hline No. of Roots & $1.40 \pm 0.09^{\mathrm{e}}$ & $2.00 \pm 0.15^{\mathrm{d}}$ & $2.60 \pm 0.09^{c}$ & $2.90 \pm 0.12^{c}$ & $3.26 \pm 0.16^{b}$ & $7.00 \pm 0.15^{\mathrm{a}}$ \\
\hline Root Length (cm) & $0.52 \pm 0.01^{\mathrm{d}}$ & $0.53 \pm 0.02^{d}$ & $0.68 \pm 0.02^{c d}$ & $0.88 \pm 0.03^{c}$ & $1.95 \pm 0.06^{\mathrm{b}}$ & $5.30 \pm 0.21^{\mathrm{a}}$ \\
\hline Fresh Weight (g) & $0.045 \pm 0^{d}$ & $0.049 \pm 0^{\mathrm{d}}$ & $0.060 \pm 0^{\mathrm{cd}}$ & $0.068 \pm 0.02^{b c}$ & $0.081 \pm 0^{b}$ & $0.369 \pm 0.01^{\mathrm{a}}$ \\
\hline Dry Weight (g) & $0.0032 \pm 0^{\mathrm{d}}$ & $0.0039 \pm 0^{\mathrm{d}}$ & $0.0051 \pm 0^{c}$ & $0.0057 \pm 0^{c}$ & $0.007 \pm 0^{b}$ & $0.0371 \pm 0^{\mathrm{a}}$ \\
\hline $\begin{array}{l}\text { Total Chlorophyll } \\
\text { (mg/g fr. wt.) }\end{array}$ & $0.25 \pm 0^{d}$ & $0.26 \pm 0^{\text {cd }}$ & $0.27 \pm 0^{\text {cd }}$ & $0.30 \pm 0^{\mathrm{bc}}$ & $0.32 \pm 0^{b}$ & $0.55 \pm 0.03^{\mathrm{a}}$ \\
\hline
\end{tabular}

NM-non-mycorrhizal; M-mycorrhizal; values are mean \pm SE; means followed by different letters in the same row are significantly different at $p<0.05$ 
Fig.1 Dendrobium chrysanthum blooming in natural habitat

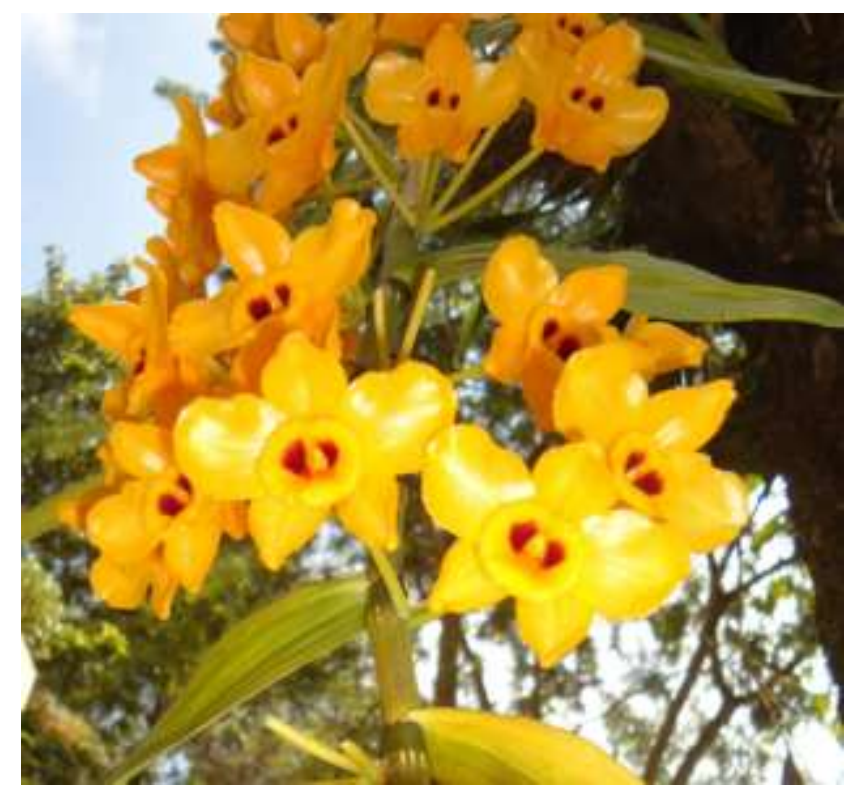

Fig.2 Percentage of root colonization under different in vitro PPFD treatments. Bars represent mean $\pm \mathrm{SE}$; bars with different letters are significantly different at $\mathrm{p}<0.05$

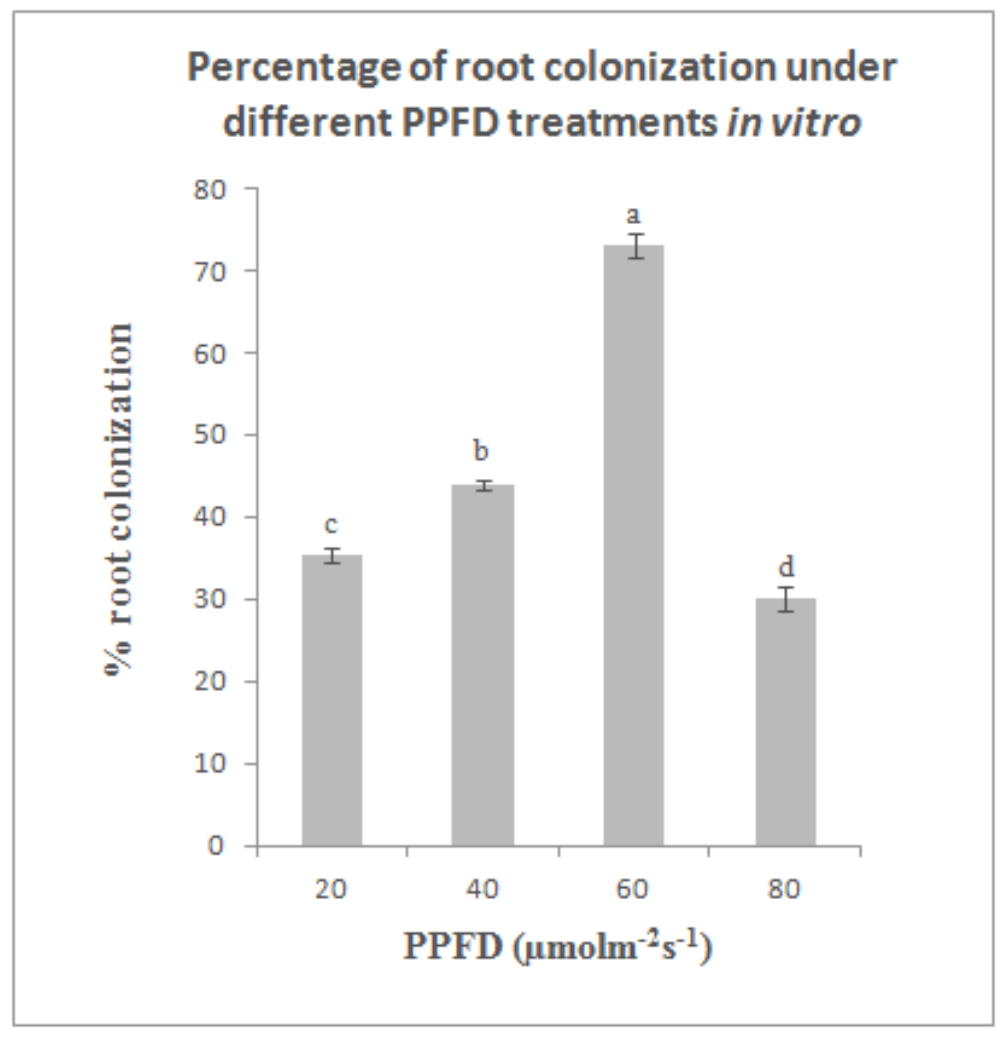


Fig.3 In vitro cultures of Dendrobium chrysanthumunder 20, 40, 60 and $80 \mu \mathrm{mol} \mathrm{m}^{-2} \mathrm{~s}^{-1} \mathrm{PPFD}$ treatments after $90 \mathrm{~d}$. Left $-\mathrm{NM}$, non-mycorrhizal; right- M, mycorrhizal. Scale bars $=5 \mathrm{~mm}$
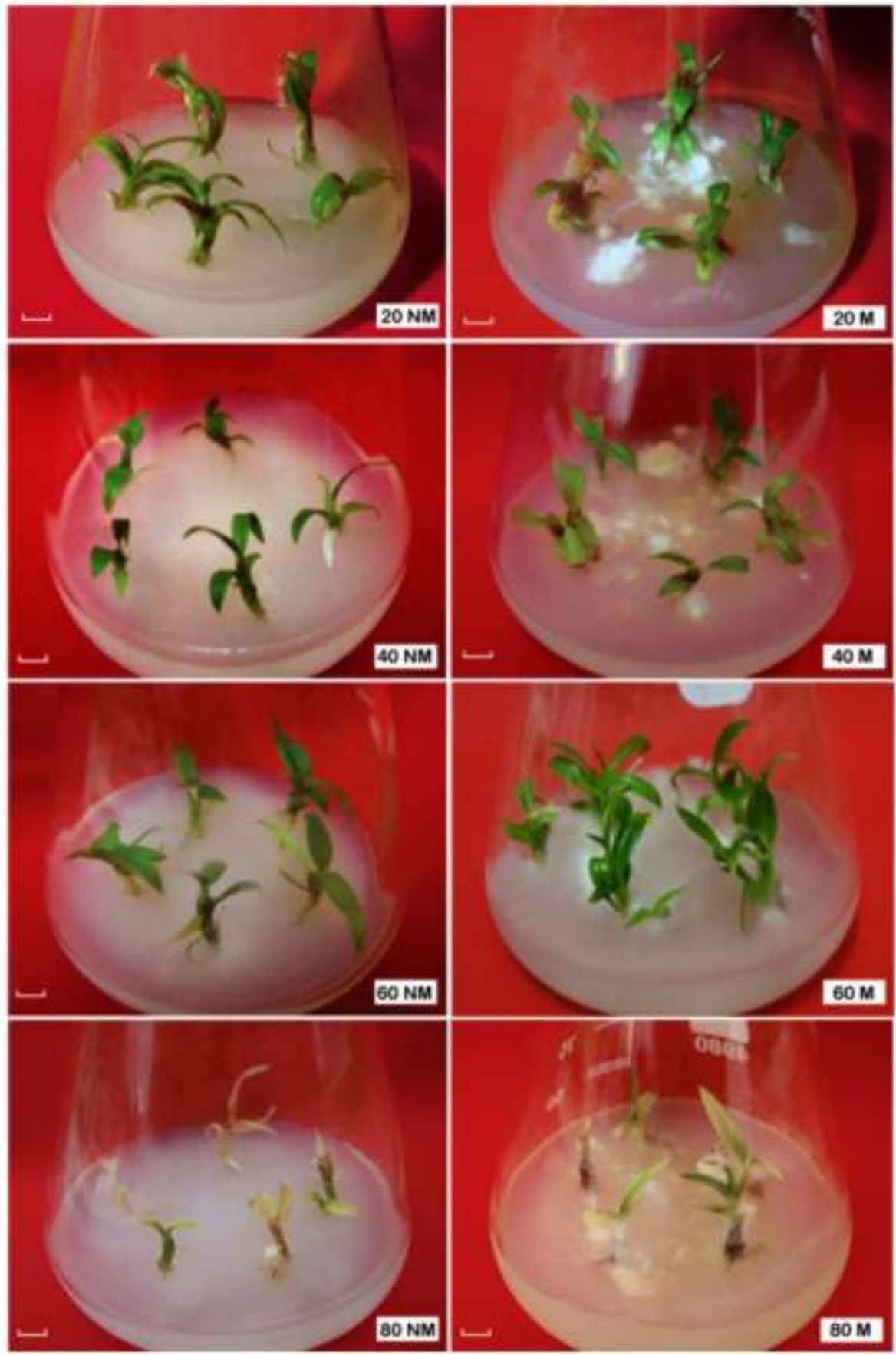
Fig.4 Scanning electron micrographs of lower epidermis of Dendrobium chrysanthum leaves after $90 \mathrm{~d}$ of in vitro culture under different PPFDs showing stomata. Left - NM, nonmycorrhizal; right- $\mathrm{M}$, mycorrhizal

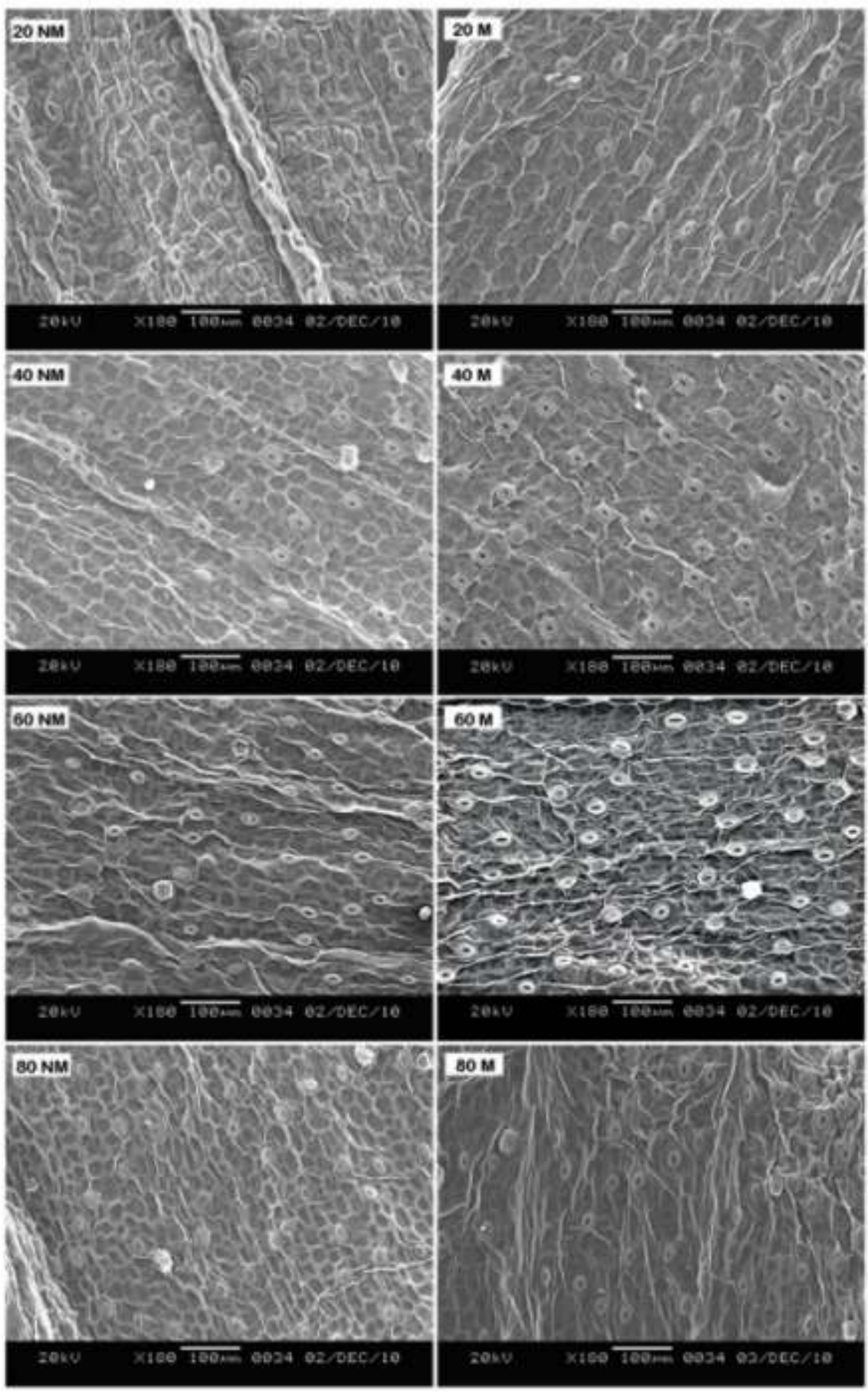


Fig.5 Effect of PPFD on survivability of non-mycorrhizal and mycorrhizal Dendrobium chrysanthum plantlets after $120 \mathrm{~d}$ of hardening. Bars represent mean $\pm \mathrm{SE}$; bars with different letters are significantly different at $\mathrm{p}<0.05$. NM, non-mycorrhizal; $\mathrm{M}$, mycorrhizal

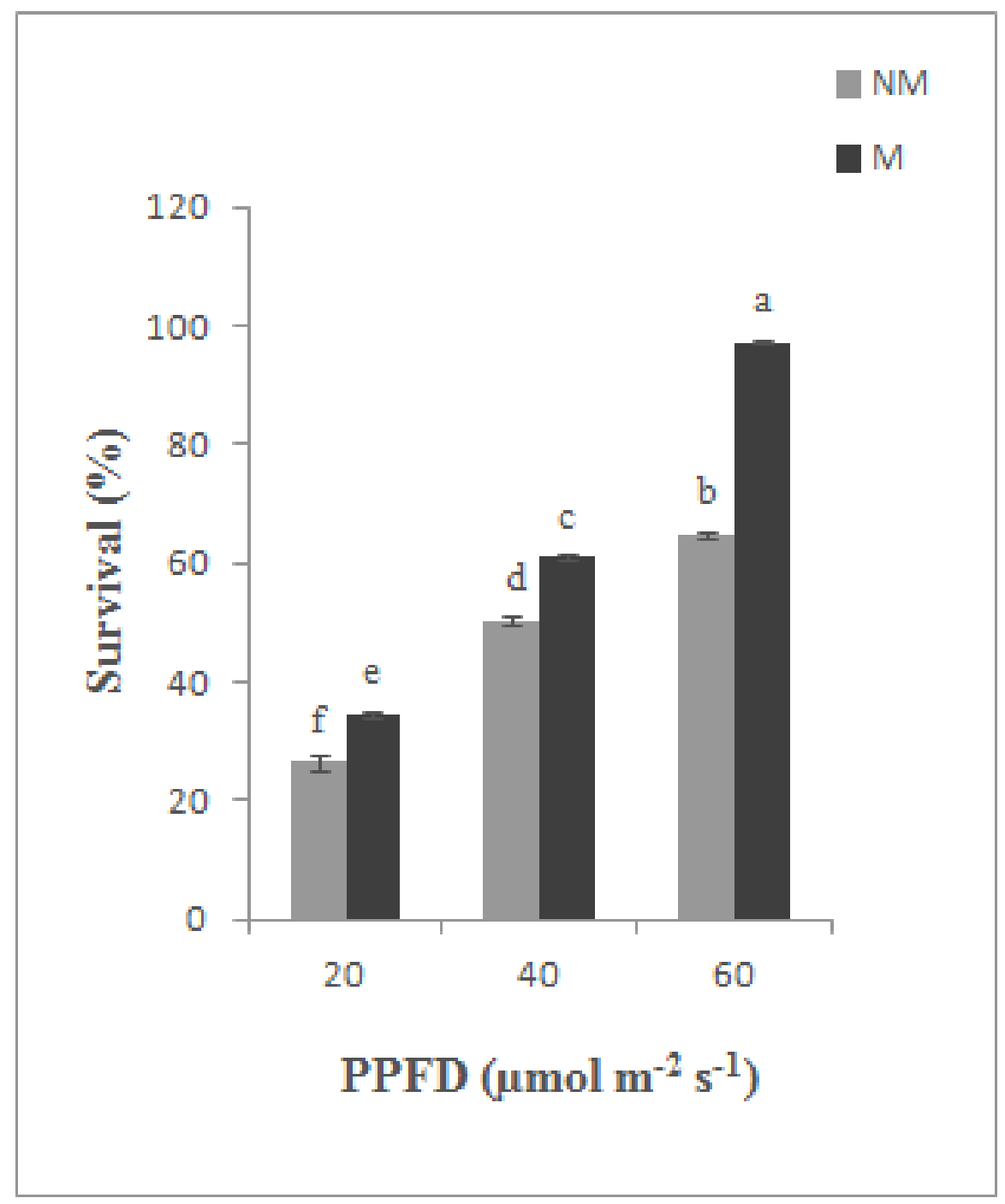


Fig.6 Plantlets after $120 \mathrm{~d}$ of hardening treated in vitro at 20,40 and $60 \mu \mathrm{mol} \mathrm{m} \mathrm{s}^{-2} \mathrm{PPFD}$. Left - NM, non-mycorrhizal; right- M, mycorrhizal. Scale bars $=5 \mathrm{~mm}$
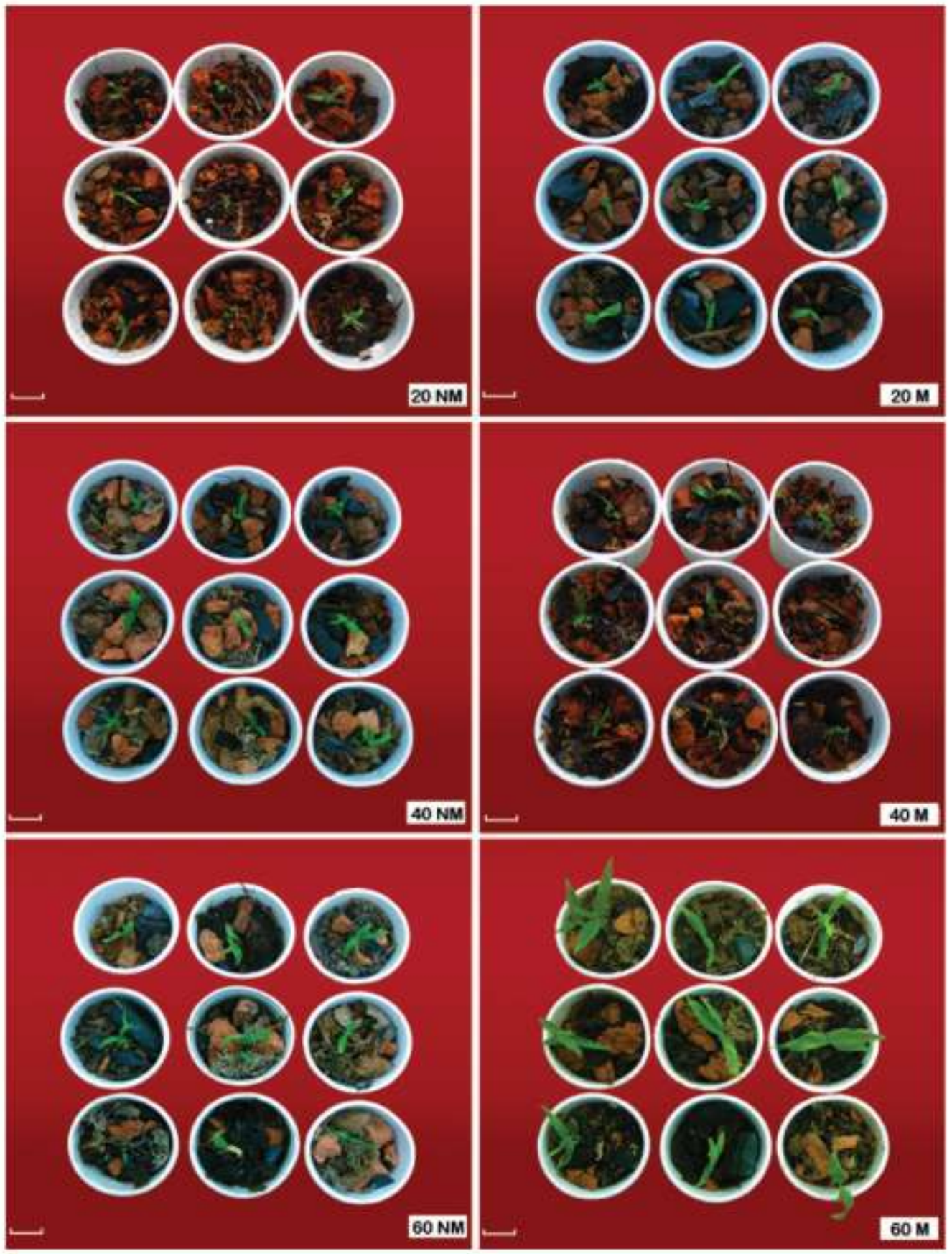
Contrary to the assumption that light intensity affects both the quantity and quality of stomata, in this study increasing light intensities only resulted in an observable increase in number of stomata per unit area of leaf and length of stomata while there was no significant effect on the width of stomata. Lee et al., (2007) reported a progressive increase in number of stomata per unit area of leaf with increasing light intensities in Withania somnifera. In the present study, both width as well as length of stomata decreased slightly at $90 \mu \mathrm{mol} \mathrm{m} \mathrm{m}^{-2} \mathrm{~s}^{-1}$ PPFD suggesting that the quantity of the stomata and not the quality is specifically under the influence of moderate light intensity.

For micropropagated plantlets, the acclimatization phase represents one of the most critical phases of micropropagation. Due to their unique characteristics, the in vitro plantlets could be subjected to high level of stress during this phase. In the present study, it was observed that inoculation of mycorrhizal fungi in vitro at optimal PPFD increased the survivability of micropropagated plantlets during acclimatization and enhanced their overall growth. Light intensity is one of the most important factors affecting ex vitro acclimatization of in vitro tissue culture plantlets (Hasegawa et al., 1973). Alvarez et al., (2012) showed that right amount of in vitro light treatment improved photochemical efficiency, developed mechanisms for excess light dissipation and improved morphological characteristics of Gevuina avellana. These characteristics accomplished during the in vitro process could help the plants endure stress during ex vitro transfer. The shock reaction to the abrupt change in irradiance during ex vitro transfer was lower in plants grown under higher PPFD in vitro (Kadlecek et al., 2001). Further, in our study, the formation of mycorrhizal fungi might have been advantageous as orchid mycorrhizal fungi have been suggested to increase ex vitro survivability of orchid seedlings, enhance vegetative and morphological growth, induce early flowering, improve flower quality, and reduce disease infection (Chang 2008). Higher survival and growth rates of micropropagated mycorrhizal plants could be attributed to enhanced translocation of nutrients between root and shoot of the mycorrhizal plants (Osonubi et al., 1991). Besides orchid mycorrhizal fungi, Glomus etunicatum, arbuscular mycorrhizal fungi have been reported to benefit acclimatization of several plants viz., anthurium, chrysanthemum and Tapeinochilos ananassae (Sohn et al., 2003; Stancato and da Silveria, 2006; Oliveira et al., 2011). Ex vitro shoot height and number of leaves were observed to be higher in arbuscular mycorrhizal fungi inoculated plantlets as compared to the non-inoculated plantlets of Psidium guajava and Sesbania sesban (Subhan et al., 1998; Estrada-Luna et al., 2000). Healthier and stronger roots were observed in micropropagted mycorrhizal plants of Leucaena leucocephala as compared to the non-mycorrhizal plants (Puthur et al., 1998). In the present study, the growth characteristics of $D$. chrysanthum mycorrhizal plantlets transferred from $60 \mu \mathrm{mol} \mathrm{m} \mathrm{m}^{-2} \mathrm{~s}^{-1}$ PPFD measured after $120 \mathrm{~d}$ of transfer were recorded to be highest. This seems to support the generally accepted presupposition that higher/optimal PPFD in vitro results in increased growth and better survival of micropropagated plantlets ex vitro.

To the best of our knowledge, this is the first report dealing with mycorrhizal association of $D$. chrysanthum in vitro at optimal PPFD which significantly produced the most marked growth response both under in vitro conditions and also during acclimatization under ex vitro environment. The integration of optimal PPFD and mycorrhizal association in vitro had an observable positive effect on the propagation of the medicinally important orchid $D$. chrysanthum both in vitro and ex vitro. 


\section{Acknowledgement}

Financial support to the first author through Rajiv Gandhi National Fellowship (RGNF) from University Grants Commission (UGC), India is gratefully acknowledged.

\section{Abbreviations}

DW, dry weight; FW, fresh weight; $\mathrm{M}$, mycorrhizal; NM, non-mycorrhizal; OMANC, oat meal agar medium; PPFD, photosynthetic photon flux density; SEM, Scanning Electron Microscope.

\section{References}

Alvarez C, Saez P, Saez K, Sanchez-Olate M, Rios D, 2012. Effects of light and ventilation on physiological parameters during in vitro acclimatization of Gevuina avellana mol. Plant Cell Tissue and Organ Culture 110: 93-101.

Amancio S, Rebordao JP, Chaves MM, 1999. Improvement of acclimatization of micropropagated grapevine: Photosynthetic competence and carbon allocation. Plant Cell Tissue and Organ Culture 58: 31-37.

Bereau M, Barigah TS, Louisanna E, Garbaye J, 2000. Effects of endomycorrhizal development and light regimes on the growth of Dicorynia guianensis Amshoff seedlings. Annals of Forest Science 57: 725-733.

Capellades M, Fontarnau R, Carulla C, Debergh $\mathrm{P}$, 1990. Environment influences anatomy of stomata and epidermal cells in tissue cultured Rose multiflora. Journal of the American Society for Horticultural Science 115(1): 141-145.

Chang DCN, 2008. Research and application of orchid mycorrhiza in Taiwan. Acta Horticulturae 766: 299-305.

Cordier C, Lemoine MC, Lemanceau P, Gianinazzi-Pearson V, Gianinazzi S, 2000. The beneficial rhizosphere: A necessary strategy for microplant production. Acta Horticulturae 530: 259-268.

Cui YY, Hahn EJ, Kozai T, Paek KY, 2000. Number of air exchanges, sucrose concentration, photosynthetic photon flux, and differences in photoperiod and dark period temperatures affect growth of Rehamannia glutinosa plantlets in vitro. Plant Cell Tissue and Organ Culture 62(3): 219-226.

Daft MJ, El-Giahmi AA, 1978. Effect of arbuscular mycorrhiza on plant growth. VIII. Effect of defoliation and light on selected hosts. New Phytologist 80: 365372.

Debergh PC, 1991. Acclimatization techniques of plants from in vitro. Acta Horticulturae 289: 291-300.

Debergh PC, De Meester J, De Riek J, Gillis S, Van Huylenbroeck J, 1992. Ecological and physiological aspects of tissue culture plants. Acta Botanica Neerlandica 41(4): 417-423.

Demmig-Adams B, Adams III, 1992. Photoprotection and other responses of plants to high light stress. Annual Review of Plant Physiology and Plant Molecular Biology 43: 599-626.

Estrada-Luna AA, Davies Jr. FT, Egilla JN, 2000. Mycorrhizal fungi enhancement of growth and gas exchange of micropropagated guava plantlets (Psidium guajava) during ex vitro acclimatization and plant establishment. Mycorrhiza 10: 1-8.

Ferguson JJ, Menge JA, 1982. The influence of light intensity and artificially extended photoperiod upon infection and sporulation of Glomus fusciculutus on Sudan grass and on root exudation of Sudan grass. New Phytologist 92: 183191.

Fitter AH, 1991. Costs and benefits of mycorrhizas: Implications for functioning under natural conditions. Experientia 47: 350-355.

Fitter AH, Garbaye J, 1994. Interactions between mycorrhizal fungi and other soil organisms. Plant Soil 159: 123-132. 
Giovannetti M, Mosse B, 1998. An evaluation of techniques for measuring vesiculararbuscular mycorrhizal infection in roots. New Phytologist 84: 489-500.

Guan DP, 2007. Influence of arbuscular mycorrhizal fungi and sugar-free culture on physiological effects of Malus pruniolia var ringo plantlets in vitro. Doctoral Dissertation of Chinese Academy of Agricultural Sciences, Beijing.

Hajong S, Kumaria S, Tandon P, 2012. Compatible fungi, suitable medium and appropriate developmental stage essential for stable association of Dendrobium chrysanthum. Journal of Basic Microbiology doi: 10.1002/jobm.201200411.

Hajong S, Kumaria S, Tandon P, 2013. Comparative study of key phosphorus and nitrogen metabolizing enzymes in mycorrhizal and non-mycorrhizal plants of Dendrobium chrysanthum Wall. ex Lindl. Acta Physiologiae Plantaraum doi 10.1007/s11738-013-1268-z.

Hasegawa PM, Murashige T, Takatori FH, 1973. Propagation of Asparagus through shoot apex culture. II. Light and temperature requirements, transplantability of plants, and cytohistological characteristics. Journal of the American Society for Horticultural Science 98: 143-148.

Hayman DS, 1974. Plant growth responses to vesicular-arbuscular mycorrhiza. VI. Effect of light and temperature. New Phytologist 73: 71-80.

Jeon MW, Ali MB, Hahn EJ, Paek KY, 2005. Effect of photon flux density on the morphology, photosynthesis and growth of a CAM orchid, Doritaenopsis during post-micropropagation acclimatization. Plant Growth Regulation 45: 139-147.

Jo EA, Tewari RK, Hahn EJ, Paek KY, 2008. Effect of photoperiod and light intensity on in vitro propagation of Alocasia amazonica. Plant Biotechnology Reports 2: 207-212.

Johnson CR, Menge JA, Schwab S, Ting IP, 1982. Interaction of photoperiod and vesicular-arbuscular mycorrhizae on growth and metabolism of sweet orange. New Phytologist 90: 665-669.

Kadlecek P, Ticha I, Haisel D, Capkova V, Schafer C, 2001. Importance of in vitro pretreatment for ex vitro acclimatization and growth. Plant Science 161: 695-701.

Lee SH, Tewari RK, Hahn EJ, Paek KY, 2007. Photon flux density and light quality induce changes in growth, stomatal development, photosynthesis and transpiration of Withania somnifera (L.) Dunal. plantlets. Plant Cell Tissue and Organ Culture 90: 141-151.

Lichtenthaler HK, 1987. Chlorophyll and carotenoids: Pigments of photosynthetic biomembranes. Methods in Enzymology 148: 350-382.

Martin F, Duplessis S, Ditengou F, Lagrange H, Voiblet C, Lapeyrie F, 2001. Developmental cross talking in ectomycorrhizal symbiosis: Signals and communication genes. New Phytologist 151: 145-154.

Oliveira JRG, Morais TAL, Melo NF, Yano-Melo AM, 2011. Acclimatization of Tapeinochilos ananassae plantlets in association with arbuscular mycorrhizal fungi. Pesquisa Agropecuaria Brasileira, Brasília 46 (9): 1099-1104.

Osonubi O, Mulongoy K, Awotoye OO, Atayese MO, Okali DU, 1991. Effects of ectomycorrhizal and vesicular arbuscular mycorrhizal fungi on drought tolerance of four leguminous woody seedlings. Plant Soil 136: 131-143.

Peyronel B, 1940. Prime osservazioni sui rapporti tra luce e simbiosi micorrizica. Lab Chanousia Giardino Botanico Alpino Piccolo San Bernard 4:1.

Pierleoni R, Vallorani L, Sacconi C, Sisti D, Giomaro G, Stocchi V, 2001. Evaluation of the enzymes involved in primary nitrogen metabolism in Tilia platyphyllos-Tuberborchii ecto mycorrhizae. Plant Physiology and Biochemistry 39: 1111-1114.

Powles SB, 1984. Photoinhibition of 
photosynthesis induced by visible light. Annual Review of Plant Physiology 35: 15-44.

Prajadinata S, Santoso E, 1993. The influence of light intensity on mycorrhizal development on Shorea spp. seedlings. In: Soerianegara I, Supriyanto (eds), Proceedings of second Asian conference on mycorrhiza. BIOTROP Special Publication 42, Bogor, pp 101-106.

Puthur JT, Prasad KVSK, Sharmila P, Saradhi PP, 1998. Vesicular arbuscular mycorrhizal fungi improves establishment of micropropagated Leucaena leucocephala plantlets. Plant Cell Tissue and Organ Culture 53: 4147.

Rabie GH, Almadani AM, 2005. Role of bio inoculants in development of salt tolerance of Vicia faba plant under salinity stress. African Biotechnology Journal 4(3): 210-222.

Smith SE, Read DJ, 1997. Mycorrhizal symbiosis. Academic Press, London.

Sohn BK, Kim KY, Chung SJ, Kim WS, Park SM, Kang JG et al., 2003. Effect of the different timing of AMF inoculation on plant growth and flower quality of chrysanthemum. Scientia Horticulturae 98: 173-183.

Stancato GC, da Silveira APD, 2006.
Associação de fungos micorrízicos arbusculares e ultivares micropropagadas de antúrio. Bragantia 65: 511-516.

Subhan S, Sharmila P, Saradhi PP, 1998. Glomus fasciculatum alleviates transplantation shock of micropropagation Sesbania. Plant Cell Reproduction 17: 268-272.

Tester M, Smith FA, Smith SE, 1985. Phosphate inflow into Trifolium subterraneum L.: Effects of photon irradiance and mycorrhizal infection. Soil Biology and Biochemistry 17: 807-810.

Thimijan RW, Heins RD, 1982. Photometric, radiometric and quantum light units of measure: A review of procedures for interconversion. HortScience 18: 818822.

Vestberg M, Kukkonen S, Saari K, Parikka P, Huttunen J, Tainio L et al., 2004. Microbial inoculation for improving the growth and health of micropropagated strawberry. Applied Soil Ecology 27: 243-258.

Zimmerman TW, Rogers SMD, Cobb BG, 1991. Controlling vitrification of petunia in vitro. In vitro Cellular and Developmental Biology-Plant 27: 165167.

\section{How to cite this article:}

Subarna Hajong, Suman Kumaria and Pramod Tandon. 2019. Synergistic Effect of PPFD and Mycorrhization for Efficient in vitro Propagation of Dendrobium chrysanthum Wall. ex Lindl.. Int.J.Curr.Microbiol.App.Sci. 8(10): 1290-1308. doi: https://doi.org/10.20546/ijcmas.2019.810.152 